\title{
Effect of Different Nanoparticles on Seed Germination and Seedling Growth in Rice
}

\author{
Yi Hao ${ }^{1, a}$, Zetian Zhang ${ }^{1, b}$, Yukui Rui ${ }^{1,3, c_{*}}$, Jingyao Ren ${ }^{1, d}$, Tianqi Hou ${ }^{1, e}$, Sijie \\ $\mathrm{Wu}^{1, \mathrm{f}}$, Mengmeng Rui ${ }^{2, \mathrm{~g}}$,Fuping Jiang ${ }^{1, \mathrm{~h}}$ and Liming $\mathrm{Liu}^{1, \mathrm{i}}$ \\ ${ }^{1}$ College of Resources and Environmental Sciences, China Agricultural University, Beijing100093, \\ People's Republic of China \\ ${ }^{2}$ College of Agriculture, Guangxi University, Nanning 530005, People's Republic of China \\ *Corresponding author

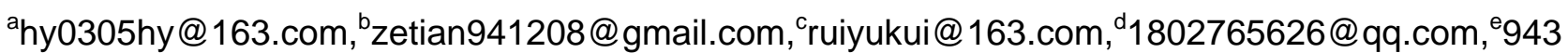 \\ 026008@qq.com, ${ }^{\mathrm{f}} 307918568 @ q q . c o m,{ }^{\mathrm{g}}$ rui.mengmeng@163.com, ${ }^{\mathrm{h}}$ 245128818@qq.com, Iiulm@ca \\ u.edu.cn,
}

Keywords: Phytotoxicity, $\mathrm{Fe}_{2} \mathrm{O}_{3} \mathrm{NPs}, \mathrm{TiO}_{2} \mathrm{NPs}$, MWCNTs, Morphologies, Size

\begin{abstract}
The aim of this study was to investigate the phytotoxicity of $\mathrm{Fe}_{2} \mathrm{O}_{3}$ nanocubes, $\mathrm{Fe}_{2} \mathrm{O}_{3}$ short nanorods, $\mathrm{Fe}_{2} \mathrm{O}_{3}$ long nanorods, $\mathrm{TiO}_{2} \mathrm{NPs}$; and MWCNTs to rice (Oryza sativa L.) seedlings during germination, including rice germination ratio, root length, shoot length and fresh weight. Our investigation found that all nanoparticles inhibited the germination of rice seeds. $\mathrm{Fe}_{2} \mathrm{O}_{3}$ nanocubes, $\mathrm{Fe}_{2} \mathrm{O}_{3}$ short nanorods, $\mathrm{Fe}_{2} \mathrm{O}_{3}$ long nanorods and $\mathrm{TiO}_{2}$ NPs all significantly promoted the root length, and stimulated shoots growth at most concentrations, but had no obvious effect on fresh weight.. Our study showed a comprehensive understanding of nanoparticles toxicity during plants germination. To our best knowledge, it was the first time to investigate the influence of $\mathrm{Fe}_{2} \mathrm{O}_{3}$ nanomaterials morphologies on plants germination.
\end{abstract}

\section{Introduction}

Nowadays, nanoscience and nanotechnology have maken rapid progress, which made it possible to synthesize and produce engineered nanoparticles (ENPs) with various types, sizes, and morphologies[1]. Among widely uses of nanoparticles, the relationship between ENPs and agriculture has been particularly attractive, considering the vital agricultural and environmental risks and the potential uses as novel fertilizers[2,3].

Recently many studies have showed the physiological responses of plant seedlings to nanoparticles during germination, but the influence of seed germination and root growth varied significantly among the plants and nanopariticles. For example, $\mathrm{TiO}_{2}$ nanoparticles could improve fennel seed germination[4]. Similarly, $\mathrm{ZnO}$ nanoparticles significant increased the germination of cucumber at the level of 400 and $1600 \mathrm{mg} \mathrm{L}^{-1}$ [5]. Lahiani et al proved that MWCNTs accelerated the germination of corn, barley, and soybean[6]. In contrast, CuO NPs decreased the germination seeds, shoot length and shoot weight of rice [7], CNTs could obviously inhibit seed gernintion of L. Sativum in sewage sludge. Ag NPs increased the germination percent of Pennisetum glaucum[8]. Meanwhile more investigations reported that nanopaticles had no effect on germination but did influence the growth of plants. For example, graphene had no obvious effects on wheat seed germination, whereas decreaseed the number of wheat roots [9]. $\mathrm{CuO}$ nanoparticles have no effects on maize seeds germination, while inhinited the root elongation[10].

The aim of our study was to investigate the bio-effect of $\mathrm{TiO}_{2} \mathrm{NPs}$, MWCNTs hematite $\left(\alpha-\mathrm{Fe}_{2} \mathrm{O}_{3}\right)$ nanoparitcles with various morphologies on seeds germination. In this study, the hybrid rice line $\mathrm{Y}$ Liangyou 1928 was selected as the model plant, different concentrations of hematite $\left(\alpha-\mathrm{Fe}_{2} \mathrm{O}_{3}\right)$ nanoparitcles, $\mathrm{TiO}_{2}$ NPs, MWCNTs were used to stimulate rice seeds. Several indexes were investigated during the germination including rice root length, shoot length, fresh weight and germination ratio. To the best of our knowledge, it is the first reports focused on the effect of seeds 
germinating after exposing to hematite $\left(\alpha-\mathrm{Fe}_{2} \mathrm{O}_{3}\right)$ nanoparitcles with different morphologies. These results will be useful for the sustainable and healthy development of nanomaterials.

\section{Materials and Methods}

\section{Sample Preparation and Characterization of the Five Nanomaterials}

$\mathrm{Fe}_{2} \mathrm{O}_{3}$ NCs (nanocubes), $\mathrm{Fe}_{2} \mathrm{O}_{3}$ SRs (short nanorod) $\mathrm{Fe}_{2} \mathrm{O}_{3}$ LRs (long nanorod) were provided by the laboratory of Dr. Liu (Tianjin University of Technology), MWCNTs were provided by the laboratory of Professor Wei Fei (Tsinghua University), $\mathrm{TiO}_{2} \mathrm{NPs}$ were purchased as a dry powder (Sigma-Aldrich Inc., USA). A transmission electron microscope (TEM) (JEM-2100, JEOL, Japan) was used to determine the morphology and size of the nanomaterials before using in experiments. All these nanomaterials were dissolved and sonicated in ethanol and then dropped onto Cu grids for the TEM observation.

All the five nanomaterials were suspended in deionized water to make the $5 \mathrm{mg} / \mathrm{L}, 10 \mathrm{mg} / \mathrm{L}, 30 \mathrm{mg} / \mathrm{L}, 50 \mathrm{mg} / \mathrm{L}, 100 \mathrm{mg} / \mathrm{L}, 150 \mathrm{mg} / \mathrm{L}$ stock suspensions followed by sonicating for 30 minutes using a sonicator to produce required concentrations for the next experiment.

\section{Seeds Treatments and Germination}

Sterilized rice seeds(Hybrid rice $\mathrm{Y}$ Liangyou 1928) were soaked in nanoparticle suspensions $\left(\mathrm{Fe}_{2} \mathrm{O}_{3} \mathrm{NCs}, \mathrm{Fe}_{2} \mathrm{O}_{3} \mathrm{SRs}, \mathrm{Fe}_{2} \mathrm{O}_{3} \mathrm{LRs}\right.$, MWCNTs, $\mathrm{TiO}_{2}$ NPs) of $5 \mathrm{mg} / \mathrm{L}, 10 \mathrm{mg} / \mathrm{L}, 30 \mathrm{mg} / \mathrm{L}, 50 \mathrm{mg} /$ $\mathrm{L}, 100 \mathrm{mg} / \mathrm{L}, 150 \mathrm{mg} / \mathrm{L}$ respctively for $2 \mathrm{~h}$, then 10 seeds were placed in every Petri dishes $(100$ $\mathrm{mm} \times 15 \mathrm{~mm}$ ) having moist filter paper inside. $5 \mathrm{~mL}$ medium containing these five NPs were added to every dishes.

\section{Determination of Growth Characteristics}

Seeds were cultivated in green house of China Agricultural University for 10 days. The number of germination was recorded every day. A seed was considered to have germinated when the shoot emerged from the seed coat and shoot length is about half of the whole seed length. And seed germination rate (GR) was calculated as the proportion of the total seeds that germinated. All seeds were irrigated with $5 \mathrm{~mL}$ DI-water once per two days during germination. After 10days seedlings were harvested. Shoot length ( $\mathrm{SL}=$ distance from the leaf base to the leaf tip) and root length ( $\mathrm{RL}=$ distance from the root base to the root tip) were measured by slide caliper. And the fresh weight of every germinated seeds was weighted by analysis balance.

Notes: Germination $(\%)=$ Number of germinated seeds/Number of Inoculated seeds $* 100 \%$

\section{Data Analysis}

Statistical analyses (one-way analysis of variance, ANOVA, and Dunnett's test) were conducted using SPSS 19.0. In all cases, a value of $p<0.05$ was considered to be statistically significant, compared to the control group.

\section{Results}

\section{Characterization of the Nanomaterials.}

The diameter of $\mathrm{Fe}_{2} \mathrm{O}_{3}$ nanocubes rang from 40nm to 100nm in the TEM images. $\mathrm{Fe}_{2} \mathrm{O}_{3}$ LRs had the length of $500 \mathrm{~nm}$ and diameter of $50 \mathrm{~nm}$, while the length of $\mathrm{Fe}_{2} \mathrm{O}_{3}$ SRs were 200-400 nm and diameter $10-20 \mathrm{~nm}$, respectively. The diameters of MWCNTs were approximately $17 \mathrm{~nm}$, the typical wall thickness ranged from approximately $3 \mathrm{~nm}$ to $7 \mathrm{~nm}$. The average size of the $\mathrm{TiO}_{2} \mathrm{NPs}$ used in the our investigation was about $20 \mathrm{~nm}$.

\section{Effects of Different NPs on Rice Root Length}

Exposure to nanoparticles $\mathrm{Fe}_{2} \mathrm{O}_{3} \mathrm{NCs}, \mathrm{Fe}_{2} \mathrm{O}_{3}$ SRs, $\mathrm{Fe}_{2} \mathrm{O}_{3}$ LRs and $\mathrm{TiO}_{2}$ NPs all significantly promoted the root length of rice seedlings at most concentrations from $5 \mathrm{mg} / \mathrm{L}$ to $150 \mathrm{mg} / \mathrm{L}$ (Figure 
1A, 1B, 1C and 1D), while exposure to CNTs had significant effects on root length only at high concentration $(150 \mathrm{mg} / \mathrm{L})$ (Figure $1 \mathrm{E}$ ). Root elongation response slightly differed between three $\mathrm{Fe}_{2} \mathrm{O}_{3} \mathrm{NPs}$ forms, exposure to $\mathrm{Fe}_{2} \mathrm{O}_{3} \mathrm{NCs}$ and $\mathrm{Fe}_{2} \mathrm{O}_{3}$ LRs promoted the root length of rice seedlings at all concentrations, while exposure to $\mathrm{Fe}_{2} \mathrm{O}_{3}$ SRs significantly promoted rice root length only at low concentrations ( $5 \mathrm{mg} / \mathrm{L}$ to $50 \mathrm{mg} / \mathrm{L}$ ) and had no significant effects at high concentrations (100 mg/L and $150 \mathrm{mg} / \mathrm{L}$ ).
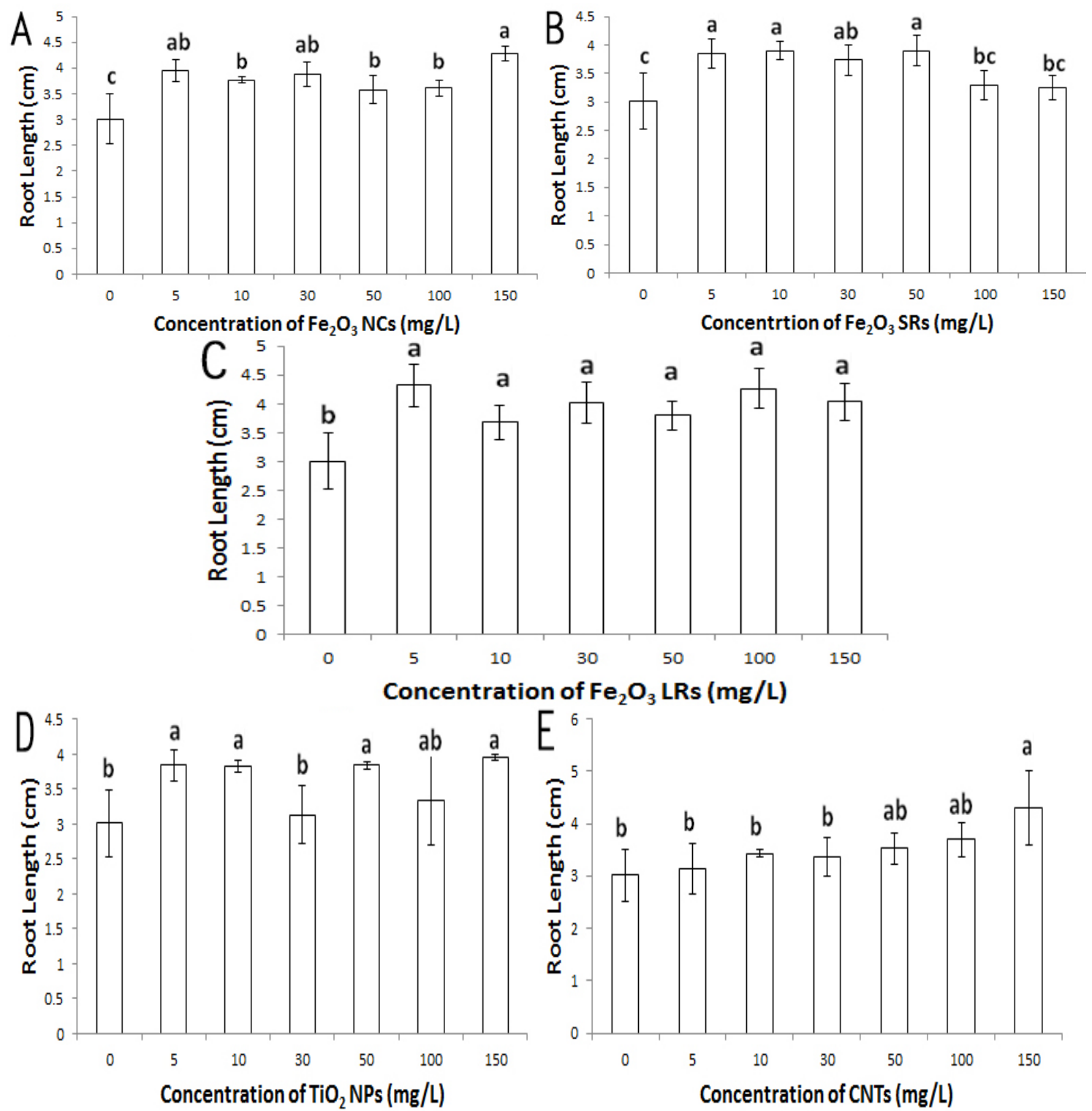

Fig. 1 Rice root length after treatments with $\mathrm{Fe}_{2} \mathrm{O}_{3} \mathrm{NCs}(\mathrm{A}), \mathrm{Fe}_{2} \mathrm{O}_{3}$ SRs (B), $\mathrm{Fe}_{2} \mathrm{O}_{3}$ LRs (C), $\mathrm{TiO}_{2}$ (D) and CNTs (E).Note: Different letters represent significant difference.

\section{Effects of Different NPs on Rice Shoot Length}

$\mathrm{Fe}_{2} \mathrm{O}_{3}$ LRs promoted shoot length at most concentrations (5 mg/L to $150 \mathrm{mg} / \mathrm{L}$ ) except $100 \mathrm{mg} / \mathrm{L}$ (Figure 2B). $\mathrm{Fe}_{2} \mathrm{O}_{3}$ SRs promoted the shoot length at low concentrations (5 mg/L and $30 \mathrm{mg} / \mathrm{L}$ ), while had no significant effects at $10 \mathrm{mg} / \mathrm{L}$ and high concentrations $(50 \mathrm{mg} / \mathrm{L}, 100 \mathrm{mg} / \mathrm{L}$ and 150 $\mathrm{mg} / \mathrm{L}$ ) (Figure 2C). But $\mathrm{Fe}_{2} \mathrm{O}_{3}$ NCs had no significantly effects on rice shoot length at all concentrations (Figure 2A). $\mathrm{TiO}_{2}$ NPs and CNTs significantly promoted the shoot length only at the highest concentration (150 mg/L) (Figure 2D and 2E). 

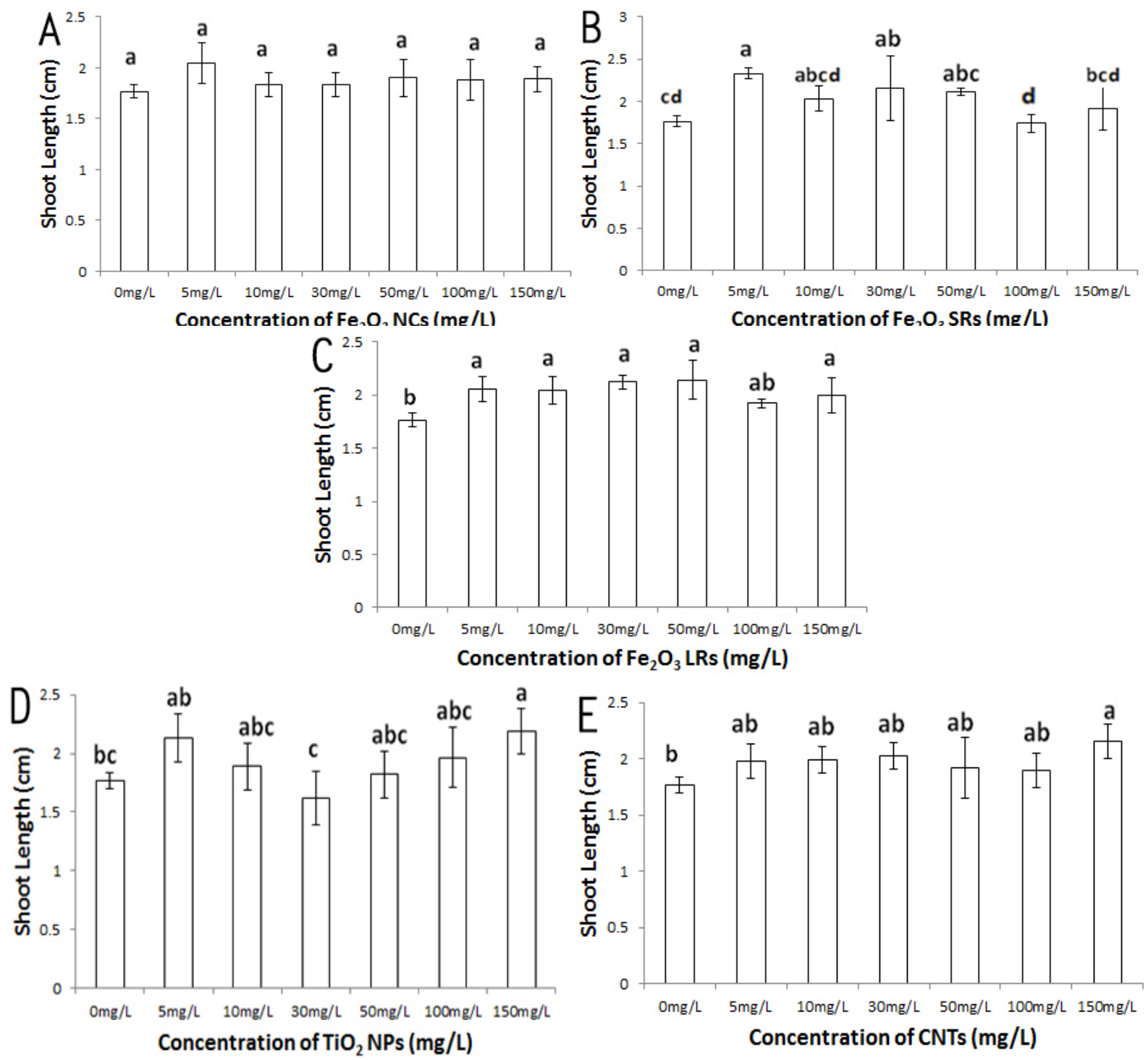

Fig. 2 Rice Shoot length after treatments with $\mathrm{Fe}_{2} \mathrm{O}_{3} \mathrm{NCs}(\mathrm{A}), \mathrm{Fe}_{2} \mathrm{O}_{3}$ SRs (B), $\mathrm{Fe}_{2} \mathrm{O}_{3}$ LRs (C), $\mathrm{TiO}_{2}$ (D) and CNTs (E).Note: Different letters represent significant difference.

\section{Effects of Different NPs on Rice Fresh Weight}

All nanoparticles had the same tendency to inhibit the fresh weight, and the effects of Fe2O3 NCs and CNTs was significant only at $10 \mathrm{mg} / \mathrm{L}$ (Figure 3A and 3E), the effects of Fe2O3 LRs on fresh weight were significant at high concentrations (100 mg/L and $150 \mathrm{mg} / \mathrm{L}$ ) (Figure 3C). Fe2O3 SRs and TiO2 NPs had no significantly effects on rice fresh weight (Figure 3B and 3D).
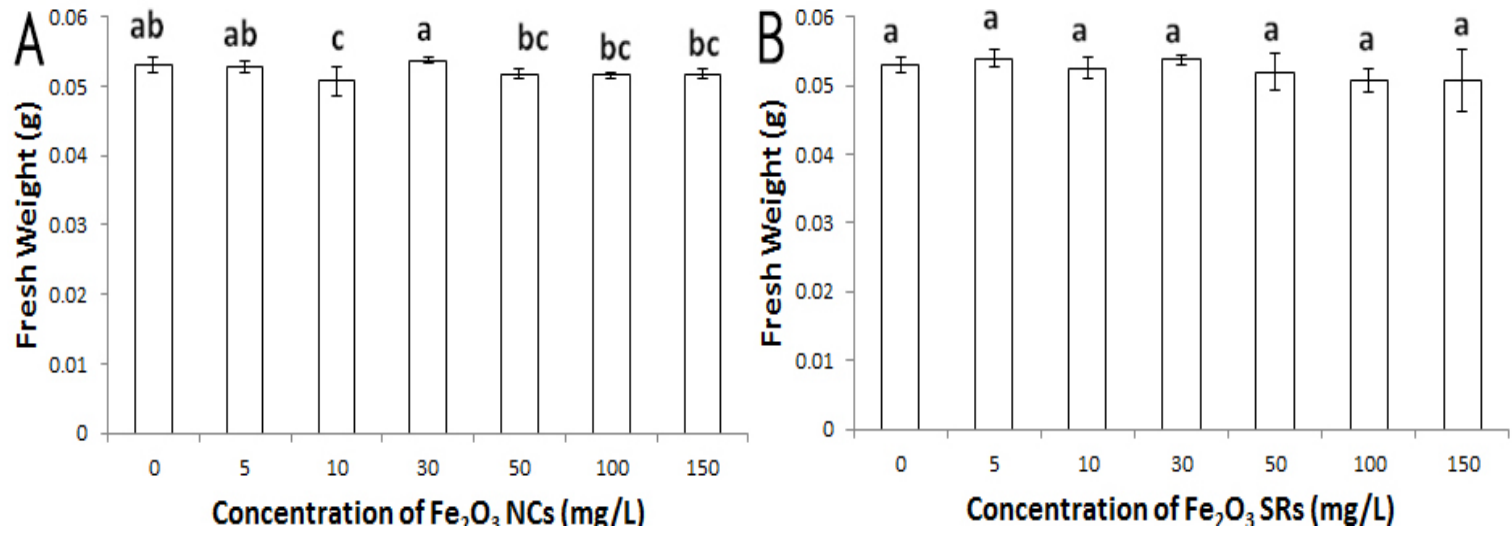

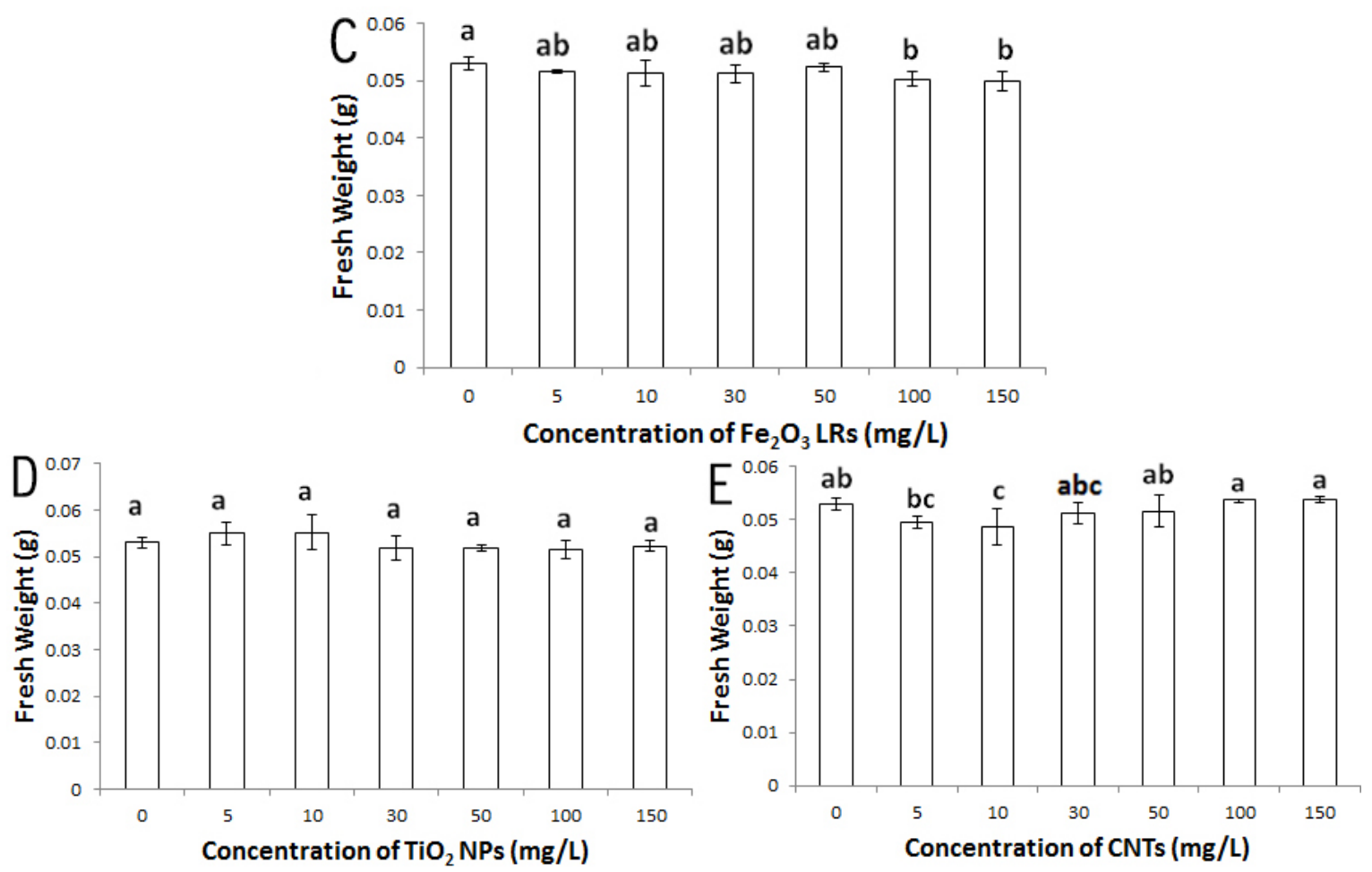

Fig. 3 Rice fresh weight after treatments with $\mathrm{Fe}_{2} \mathrm{O}_{3} \mathrm{NCs}(\mathrm{A}), \mathrm{Fe}_{2} \mathrm{O}_{3}$ SRs (B), $\mathrm{Fe}_{2} \mathrm{O}_{3}$ LRs (C), $\mathrm{TiO}_{2}$ (D) and CNTs (E).Note: Different letters represent significant difference.

\section{Effects of Different NPs on Rice Germination Ratio}

All nanoparticles inhibited the germination of rice seeds, while only $\mathrm{Fe}_{2} \mathrm{O}_{3}$ LRs, $\mathrm{TiO}_{2}$ and CNTs had significant effects (Figure 4A, 4B, 4C, 4D, 4E). These data proved that nanoparticles could affected the seed germination, which depends on the elements composition and forms of nanoparticles.
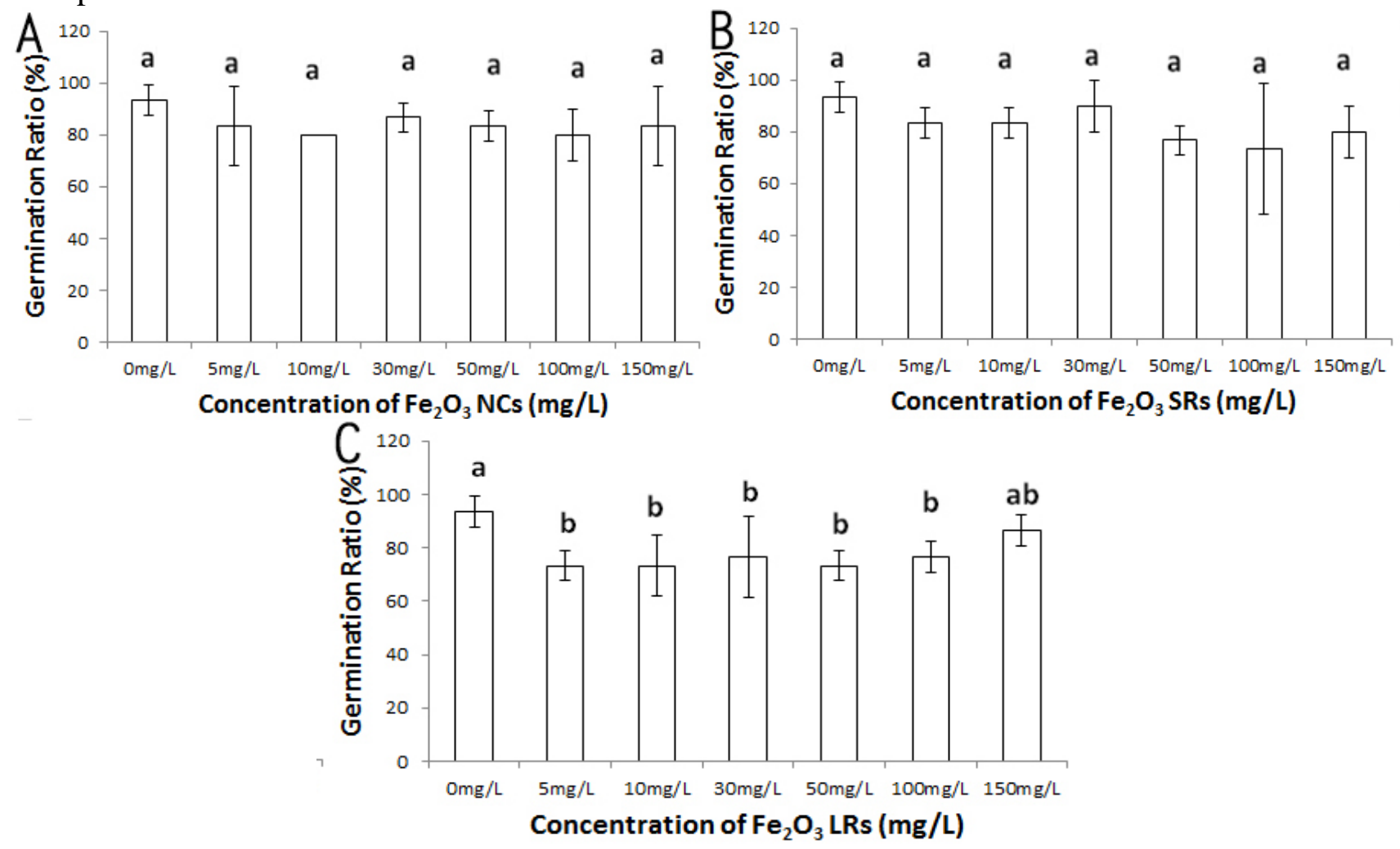

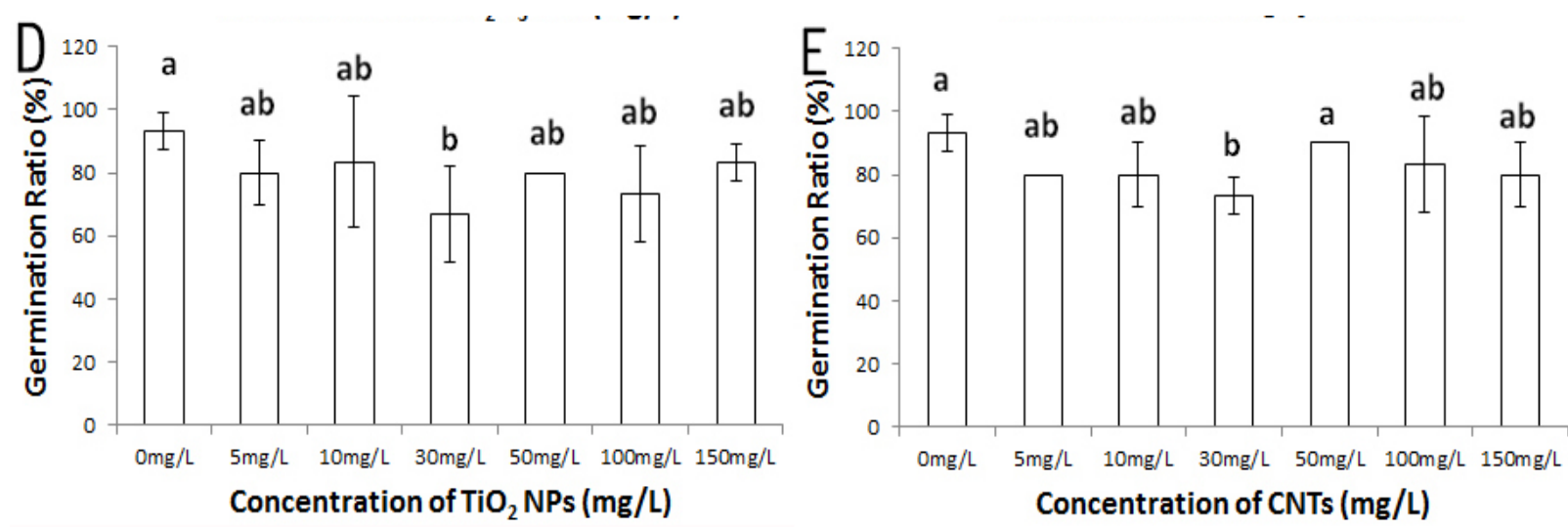

Fig. 4Rice germination ratio after treatments with $\mathrm{Fe}_{2} \mathrm{O}_{3} \mathrm{NCs}(\mathrm{A}), \mathrm{Fe}_{2} \mathrm{O}_{3} \mathrm{SRs}(\mathrm{B}), \mathrm{Fe}_{2} \mathrm{O}_{3} \mathrm{LRs}(\mathrm{C})$, $\mathrm{TiO}_{2}$ (D) and CNTs (E).Note: Different letters represent significant difference.

\section{Discussion}

$\mathrm{Fe}_{2} \mathrm{O}_{3}$ NPs with various morphologies had different crystal plane effect on CO catalytic oxidation[11]. In our study, $\mathrm{Fe}_{2} \mathrm{O}_{3}$ nanomaterials had no effect on fresh weight, and almost all concentration of these three $\mathrm{Fe}_{2} \mathrm{O}_{3}$ NPs promoted the elongation of rice seedlings significantly,which coincided with previous report [12]. This positive effect could due to the the greater bioavailability of iron molecules to the seed radicals[13] and the the higher solubility of $\mathrm{Fe}_{2} \mathrm{O}_{3}$ NPs in suspension[12]. Notebly, considering the different sizes, morphologies of NPs and differents plants species, the acquisition strategies of Fe elements as the nanoparticulates may not always effective[14].

In our study, $\mathrm{Fe}_{2} \mathrm{O}_{3} \mathrm{NCs}$ and $\mathrm{Fe}_{2} \mathrm{O}_{3}$ SRs had no obvious effect on germination, but $\mathrm{Fe}_{2} \mathrm{O}_{3}$ LRs inhibited this crucial index siginificantly. These interesting phenomenon seems can be largely due to the nanomaterials' morphologies. Recently it was reported that AgNPs have higher toxicity than AgNCs and AgNWs, which indicated the influence of nanomaterials on plants[15]. Xiang et.al found that $\mathrm{ZnO}$ hexagonal nanorod and $\mathrm{ZnO}$ nanocolumniation showed different bio-effect to Chinese cabbage seeds[16]. Different morphologies may affect dissolution, uptake, stability of nanomaterials [15], result into gene expression alteration [17], further affect plants growth. Our study demonstrated that $\mathrm{Fe}_{2} \mathrm{O}_{3}$ long nanorods had higher toxicity on germination than $\mathrm{Fe}_{2} \mathrm{O}_{3}$ nanocubes and $\mathrm{Fe}_{2} \mathrm{O}_{3}$ short nanorods, but the machanism need to be further investigated.

The bio-effect of CNTs have evaluated on various organisms, such as aquatic animals, bacteria and higher plants[18]. As showed in our study, it was obvious that MWCNTs promoted the growth of rice roots, shoots and fresh weights after 10days' exposure, which identified with previous studies[19]. Notably, these positive responses amplified significantly with the increased concentration. The promotive effect reached the top at the concentration of $150 \mathrm{mg} / \mathrm{L}$, which was the highest concentration in our investigation. These promoted effects could be explained in the perspective of relative genes' expression, especially the expression of cell division genes and water channel genes[20,21].

$\mathrm{TiO}_{2}$ NPs stimulated the growth of rice roots and shoots at almost all concentrations, especially at the low concentration $(5 \mathrm{mg} / \mathrm{L})$, and the high concentration $(150 \mathrm{mg} / \mathrm{L})$, which accorded with previous reports[22], it seems that relative low concentration could promoted the growth of rice shoots and roots in our experimental condition. These positive responses could due to the amplified uptake of the water and nutrient by the treated seeds[22]. The relative tiny diameter of $\mathrm{TiO}_{2}$ NPs(about 20nm), which was susceptive to plant roots[23].

\section{Conclusions}

In this study, we investigated the bio-effect of $\mathrm{Fe}_{2} \mathrm{O}_{3}$ nanocubes, $\mathrm{Fe}_{2} \mathrm{O}_{3}$ short nanorods, $\mathrm{Fe}_{2} \mathrm{O}_{3}$ long nanorods, MWCNTs, $\mathrm{TiO}_{2}$ NPs on rice germination, root length, shoot length and fresh weight. All 
nanomaterials stimulated roots elongation and promoted shoots growth at most concentrations, but had no obvious effect on fresh weight. $\mathrm{Fe}_{2} \mathrm{O}_{3}$ long nanorods, MWCNTs, and $\mathrm{TiO}_{2} \mathrm{NPs}$ inhibited the seeds germination significantly. While this negative effect on rice germination was not significant in the group of $\mathrm{Fe}_{2} \mathrm{O}_{3}$ short nanorods and $\mathrm{Fe}_{2} \mathrm{O}_{3}$ nanocubes. It seemed that $\mathrm{Fe}_{2} \mathrm{O}_{3}$ long nanorods had different bio-effect on germination from other $\mathrm{Fe}_{2} \mathrm{O}_{3}$ nanomaterials, mainly due to their different shapes. The underlying machanism need to be further investigated. To our best knowledge, it was the first time to investigate the influence of $\mathrm{Fe}_{2} \mathrm{O}_{3}$ nanomaterials morphologies on plants during germination. It was significant to investigate the influence of nanomaterials morphologies on phytotoxicity, and the mechanism need to further study.

\section{Acknowledgments}

The project was supported by the National Natural Science Foundation of China (No.41371 471), the Key National Natural Science Foundation of China (No. 41130526)and the NSFCGuangdong Joint Fund (U1401234).

\section{Reference}

[1] X. Gui, X. He, Y. Ma, P. Zhang, Y. Li, Y. Ding, K. Yang, H. Li, Y. Rui, Z. Chai, Y. Zhao, Z. Zhang, Quantifying the distribution of ceria nanoparticles in cucumber roots: the influence of labeling,RSC Adv., 5(2015)4554-4560.

[2] L.V. Nhan, C. Ma, Y. Rui, S. Liu, X. Li, B. Xing, L. Liu, Phytotoxic Mechanism of Nanoparticles: Destruction of Chloroplasts and Vascular Bundles and Alteration of Nutrient Absorption,Scientific Reports, 5(2015)11618.

[3] R. Liu, R. Lal, Potentials of engineered nanoparticles as fertilizers for increasing agronomic productions,Sci Total Environ, 514(2015)131-139.

[4] H. Feizi, M. Kamali, L. Jafari, P. Rezvani Moghaddam, Phytotoxicity and stimulatory impacts of nanosized and bulk titanium dioxide on fennel (Foeniculum vulgare Mill),Chemosphere, 91(2013)506-511.

[5] G. de la Rosa, M.L. López-Moreno, D. de Haro, C.E. Botez, J.R. Peralta-Videa, J.L. Gardea-Torresdey, Effects of ZnO nanoparticles in alfalfa, tomato, and cucumber at the germination stage: Root development and X-ray absorption spectroscopy studies,Pure Appl Chem, 85(2013).

[6] M.H. Lahiani, E. Dervishi, J. Chen, Z. Nima, A. Gaume, A.S. Biris, M.V. Khodakovskaya, Impact of Carbon Nanotube Exposure to Seeds of Valuable Crops,ACS Applied Materials \& Interfaces, 5(2013)7965-7973.

[7] A.K. Shaw, Z. Hossain, Impact of nano-CuO stress on rice (Oryza sativa L.) seedlings,Chemosphere, 93(2013)906-915.

[8] A. Parveen, S. Rao, Effect of Nanosilver on Seed Germination and Seedling Growth in Pennisetum glaucum,J Clust Sci, 26(2015)693-701.

[9] X. Hu, L. Mu, J. Kang, K. Lu, R. Zhou, Q. Zhou, Humic Acid Acts as a Natural Antidote of Graphene by Regulating Nanomaterial Translocation and Metabolic Fluxes,Environ Sci Technol, 48(2014)6919-6927.

[10] Z. Wang, X. Xie, J. Zhao, X. Liu, W. Feng, J.C. White, B. Xing, Xylem- and Phloem-Based Transport of CuO Nanoparticles in Maize (Environ Sci Technol, 46(2012)4434-4441.

[11] X. Liu, J. Liu, Z. Chang, X. Sun, Y. Li, Crystal plane effect of $\mathrm{Fe}_{2} \mathrm{O}_{3}$ with various morphologies on CO catalytic oxidation,Catalysis Communications, 12(2011)530-534.

[12] D. Alidoust, A. Isoda, Effect of $\gamma \mathrm{Fe}_{2} \mathrm{O}_{3}$ nanoparticles on photosynthetic characteristic of 
soybean (Glycine max (L.) Merr.): foliar spray versus soil amendment,Acta Physiol Plant, 35(2013)3365-3375.

[13] C.A. Dehner, L. Barton, P.A. Maurice, J.L. DuBois, Size-Dependent Bioavailability of Hematite $\left(\mathrm{a}-\mathrm{Fe}_{2} \mathrm{O}_{3}\right)$ nanoparticles to a common aerobic bacterium,Environ Sci Technol, 45(2011)977-983.

[14] Y. Marusenko, J. Shipp, G.A. Hamilton, J.L.L. Morgan, M. Keebaugh, H. Hill, A. Dutta, X. Zhuo, N. Upadhyay, J. Hutchings, P. Herckes, A.D. Anbar, E. Shock, H.E. Hartnett, Bioavailability of nanoparticulate hematite to Arabidopsis thaliana,Environ Pollut, 174(2013)150-156.

[15] D.E. Gorka, J.S. Osterberg, C.A. Gwin, B.P. Colman, J.N. Meyer, E.S. Bernhardt, C.K. Gunsch, R.T. DiGulio, J. Liu, Reducing Environmental Toxicity of Silver Nanoparticles through Shape Control,Environ Sci Technol, 49(2015)10093-10098.

[16] L. Xiang, H. Zhao, Y. Li, X. Huang, X. Wu, T. Zhai, Y. Yuan, Q. Cai, C. Mo, Effects of the size and morphology of zinc oxide nanoparticles on the germination of Chinese cabbage seeds,Environ Sci Pollut R, 22(2015)10452-10462.

[17] Y. Syu, J. Hung, J. Chen, H. Chuang, Impacts of size and shape of silver nanoparticles on Arabidopsis plant growth and gene expression,Plant Physiol Bioch, 83(2014)57-64.

[18] J. Du, S. Wang, H. You, X. Zhao, Understanding the toxicity of carbon nanotubes in the environment is crucial to the control of nanomaterials in producing and processing and the assessment of health risk for human: A review,Environ Toxicol Phar, 36(2013)451-462.

[19] A. Mondal, R. Basu, S. Das, P. Nandy, Beneficial role of carbon nanotubes on mustard plant growth: an agricultural prospect,Journal of Nanoparticle Research, 13(2011)4519-4528.

[20] M.H. Lahiani, E. Dervishi, J. Chen, Z. Nima, A. Gaume, A.S. Biris, M.V. Khodakovskaya, Impact of Carbon Nanotube Exposure to Seeds of Valuable Crops,ACS Applied Materials \& Interfaces, 5(2013)7965-7973.

[21] M.V. Khodakovskaya, K. de Silva, A.S. Biris, E. Dervishi, H. Villagarcia, Carbon Nanotubes Induce Growth Enhancement of Tobacco Cells,ACS Nano, 6(2012)2128-2135.

[22] E.H. Dehkourdi, M. Mosavi, Effect of Anatase Nanoparticles $\left(\mathrm{TiO}_{2}\right)$ on Parsley Seed Germination (Petroselinum crispum) In Vitro,Biol Trace Elem Res, 155(2013)283-286.

[23] C. Larue, J. Laurette, N. Herlin-Boime, H. Khodja, B. Fayard, A. Flank, F. Brisset, M. Carriere, Accumulation, translocation and impact of $\mathrm{TiO}_{2}$ nanoparticles in wheat (Triticum aestivum spp.): Influence of diameter and crystal phase,Sci Total Environ, 431(2012)197-208. 